\title{
The Use of Suggestopedia to Solve Students' Literacy Difficulties
}

\author{
Erna Sundari ${ }^{1, *}$ Hari Prastyo $^{2}$ Desi Wulandari ${ }^{3}$ Santi H. Saputri ${ }^{4}$ Shiva Fauziah $^{5}$ \\ Masruchan Mahpur ${ }^{6}$
}

${ }^{1}$ MTsN 11 Tasikmalaya, Ministry Religion of West Java, Tasikmalaya, Indonesia

${ }^{2}$ Islam Education Department Institut Agama Islam Uluwiyah, Mojokerto, Indonesia

${ }^{3}$ Postgraduate, Science of Education Universitas Negeri Surabaya Surabaya, Indonesia

${ }^{4}$ MAN 5 Garut, Ministy Religion of West Java Garut, Indonesia

${ }^{5}$ MAN 1 Jepara, Ministry Religion of Central Java Jepara, Indonesia

${ }^{6}$ MA Al Kautsar, Ministry Religion of East Java Trenggalek, Indonesia

*Corresponding author. Email: ernasundari56@gmail.com

\begin{abstract}
This research is entitled learning to write descriptions through the suggestopedia method to solve students' literacy difficulties for students who have difficulty writing experimental studies in $7^{\text {th }}$ grade in MTs Negeri 11 Tasikmalaya. This research is motivated by students who have difficulty writing descriptive texts. This study aims to determine the success of using suggestopedia method on students with learning difficulties in writing descriptions. The suggestopedia method is considered capable of overcoming students' learning difficulties because the method tends to make the atmosphere relaxed and comfortable, supported by good classroom arrangements and soothing music so that students can concentrate well and be happy. The focus of this research is six students who have writing difficulties. To find out the effectiveness of the suggestopedia method in students with writing difficulty, t-test statistics is used. This research results in an increase in the ability to write descriptive text after using the suggestopedia method.
\end{abstract}

Keywords: Students, Effectiveness, Writing, Method.

\section{INTRODUCTION}

The development of an individual can be affected by the acquisition of language. This acquisition includes spoken and written language. These developments require basic skills, namely speech and writing skills. According to linguists, writing skills are at the highest level in language acquisition. Writing skills are generated after someone masters the listening, speaking, and reading skills. This also causes writing skills to be considered difficult by some people. Although writing skills are considered difficult, they have a crucial role in human life [20]. Writing skills indicate the progress of the nation. Learning to write for each child is certainly different depending on their interests, talents, and abilities. Some children easily learn to write so that they produce good and easy-to- read writing, but some children have difficulty learning to write so that they produce illegible writing.

The process of learning to write can also be seen from the activities of students in expressing their ideas and thoughts through writing. However, some students have difficulty in expressing their ideas and thoughts. Learning to write has long been a problem in the Indonesian language learning system [19]. Several factors that are considered to contribute to the failure to achieve writing goals are low level of vocabulary mastery as a result of low interest in reading, lack of mastery of micro language skills, difficulty in finding writing learning methods that are suitable for students' conditions and abilities, and the absence or limitation of writing learning media. Children who have writing difficulties tend to be introverted and have difficulty socializing, but sometimes, they have a prominent 
character among their friends. Based on this, students in schools in the writing learning group can be categorized into two groups. The first group is a group of students who have talents, interests, and good writing skills. In contrast, the second group is students who have writing difficulties. Students who have learning difficulties in writing are defined as students who have disabilities in learning to write. Learning difficulties are caused by problems experienced by the brain in receiving, processing, analyzing, and storing information. In this case, inability is defined as a psychological disorder that includes a basic understanding of the use of written language [10].

Based on research conducted in March 2019, the researchers found cases related to learning difficulties in description experienced by $7^{\text {th }}$ grade students at Public Madrasah Tsanawiyah (junior secondary) or MTsN 11 Tasikmalaya. Students had difficulty expressing ideas in writing, especially writing descriptive text. In addition, the resulting writing is difficult to read because the shape of the letters written is not following the rules of writing the correct word. Another difficulty is determining an object to be written in addition to compiling the collected data into a text. In this case, it can be said that the student has difficulty learning to write descriptions at the intermediate level. The Indonesian language teacher said that the student had been treated by presenting writing exercises but had not shown significant results, so special training was needed to handle them. To handle these cases, the researchers applied a writing learning method, namely the suggestive learning method. Learning to write descriptive text was chosen because this activity requires a lot of vocabulary to apply the suggested method in this lesson. The use of the suggestopedia method in learning to write descriptions can improve students writing skills. Suggestopedia plays a role in stimulating the memory and personality of students so that structured, meaningful content is needed and an artistic approach is used [6]. The art lies in the use of music, drama, dance performances, as well as the use of the media of pictures or paintings. It serves to create an atmosphere that can increase student motivation. Greater emphasis is placed on the use of grammar. The purposes of this study are (1) to determine the case profile of students with writing difficulties, (2) to find out what factors caused students to have difficulty in learning to write,
(3) to determine the improvement in the ability to write descriptions of students with writing difficulties after being treated with suggestopedia method, (4) to determine students' perceptions of learning to write descriptions using the suggestopedia method. The benefit of this research is that teachers can use the suggestopedia method as an alternative in learning activities related to learning difficulties faced by students. In addition, this research is expected to be a reference for solving problems related to writing difficulties, especially writing descriptive texts faced by students.

\subsection{Theoretical basis}

\subsubsection{Suggestopedia}

Suggestopedia comes from the word suggestology, the science of non-rational and non-conscious influences on humans [21]. The method, which was first introduced by a physicist named George Lozanov around 1978, believes that relaxation and concentration techniques will help students open their subconscious sources and will eventually acquire and master the required quantity of vocabulary more than they thought. Suggestopedia is a teaching system that makes use of all the possible tender suggestions can offer. Of course, systematic academic participation is not neglected but is always in accord with the suggestive. Suggestopedia is a teaching system that can take advantage of all the possibilities. In addition, systematic academic participation cannot be ignored because it can provide suggestions to be achieved.

The most striking features of suggestopedia are classroom decoration, classroom furniture, class arrangement, use of music, and authoritative teacher. Bright classroom paint colors, posters containing motivational words, placement of student chairs and desks, and class knick-knacks can motivate students. Learning is also accompanied by music that can make students relax but not fall asleep. Lozanov suggested the use of classical music. Playing music in a class arranged based on the characteristics described above can provide positive suggestions. The teachers' attitude who dominates the class determines the suggestopedia method's success. The teacher becomes a facilitator and initiator who regulates the continuity of learning. The most conspicuous characteristics of suggestopedia are the decoration, furniture, and arrangement of the 
classroom, the use of music, and the authoritative behavior of the teacher. The characteristics of suggestopedia are a kind of tool to increase student interest [21]. This confirms that the use of classroom decorations, comfortable furniture for students and classroom arrangements, and the use of music in learning activities, as well as the teacher's attitude who dominates the class, are characteristics of the suggestopedia method.

Music plays an important role in the use of this suggestopedia. Teachers can choose music according to the characteristics of students. The inventor of this method recommended the use of classical music so that it could be one of the considerations. However, not all students like classical music, especially students with low levels of education, elementary and middle school students, or students from rural areas or villages. Another alternative is selecting regional instrument music and music with an interesting theme. The music used in this research is music with the theme of natural scenery and regional music instruments. The use of music is the main step in learning activities in the concept phase [23]. The teacher gives the material to the students accompanied by music. This step can create communication in two ways. First, students can capture linguistic messages from song lyrics or readings that are read when music is played. The second is the factor that completes the linguistic message. Like people who are watching a concert, students' psyche will be calm and relaxed so that students' psychological barriers will be reduced or almost forgotten. The use of music in learning will help students avoid learning saturation so that they can give meaning to linguistic material. Intonation and rhythm are combined in a musical background. The background music can help encourage a relaxed attitude in pseudo passivity. The role of music helps to learn to be more suggestive of releasing tension and increasing students' concentration [9].

Each learning method has its strengths and weaknesses [14], namely:

1. The advantages of the Suggestopedia method are that it provides calm and relaxation because it is accompanied by music that makes children relax, fun, and exciting. Classrooms that have been modified as attractively as possible stimulate excitement for children, accelerate the learning process and emphasize the development of language skills.

2. The weakness of the suggestopedia method, it can only be used in small groups, for students who do not like classical music or instruments, it will be annoying and increase anxiety, modifying the class requires a high cost, there are no provisions for implementation and preparation for intermediate and advanced students, for the level of reading comprehension and writing comprehension level, the scope of the use of the suggestopedia method is too limited, the input material is pedagogically prepared more exclusively.

\subsection{The Nature of Writing}

For some people, reading is easier than writing. However, writing skills are indispensable in everyday life, both at school and in the community. Writing activities are lowering or painting graphic symbols that describe a language that someone understands so that other people can read the graphic symbols. Pictures and symbols may convey meaning but do not convey language units [1]. The writing is pouring ideas into a visual form. Writing is expressing language in the form of symbols and images [2]. We can conclude that writing is a language activity that communicates language symbols, symbols, or images that express thoughts, feelings, and ideas for communication and note-taking purposes, which are strongly influenced by cognitive abilities. The writing process requires a long time. The writing process is carried out after the child has passed the previous language skills phase, namely listening, speaking, and reading. Writing skill is the highest skill because children can write a word from the process of listening and speaking. There are three categories in writing as follows [24].

\section{Imitation writing}

This category includes the ability to spell correctly. The students must attain skills in basic tasks such as writing letters and using punctuation in a sentence. This category is applied to the elementary school level.

\section{Writing-intensive (controlled)}

In this category, most of the assessment tasks focus on the text's form and design. Students must achieve skills in generating appropriate vocabulary according to the correct context, collocations, idioms, and 
language features. This category is set for the junior high school level.

\section{Responsive writing}

This level requires students to perform a limited level of discourse, creating a connected logical sequence of two or three paragraphs. It is more focused on the conventions of discourse according to the purpose of the written text. It has a strong emphasis on context and meaning. This field of writing skills is intended for high school students.

\subsection{Paragraph Description}

Paragraph description is a type of writing related to an effort made by the author to describe the object described in more detail. The word description comes from the Latin describe, which means to describe something. According to the Indonesian Dictionary (KBBI, Kamus Besar Bahasa Indonesia), a description is a clear and detailed description or description in words. In essence, descriptive text is a text that describes an object, thing, or object in detail. Essentially, descriptive writing is an attempt to describe something in words form or outward nature of an object. A writer will try to describe the impression of observations through feelings to the reader by revealing the properties and details of an object [18].

From some of the experts' opinions above, a descriptive essay can be said to contain a description of an object being observed. This observation is done with the help of the human senses. In addition, the descriptive essay must be described clearly and in detail so that the reader knows the object being described without seeing the object it describes directly. The pattern of presenting the description includes the observable object or phenomenon issue. The patterns in the point of view are as follows [11].

1. Static patterns, authors, and observers are staying still or not moving. They can cast their eyes on the described place by following an orderly sequence.

2. The pattern of moving, looking at a place, object, or thing in terms of moving.

3. The outline pattern, if a place, object, or thing is difficult to describe because it is too broad and large, then make a description that is a framing picture of the place being described.
A few students have difficulty in writing descriptive texts, even though they have received guidance from the teacher. The difficulties experienced by students are in the form of difficulties in developing an idea into the main idea in a paragraph. Sometimes students develop several main ideas in one paragraph. This makes sense because writing is considered the most difficult among the four language skills. Writing is a thought process because there is a process of putting ideas into writing to turn thoughts into words in a coherent organization [7].

\subsection{The Nature of Learning Difficulties}

Difficulties or disabilities in learning cannot be recognized in a physical form This happens differently in students with disabilities from other normal people. Learning difficulties are not as handicapped as paralysis or blindness. Learning difficulties are deficiencies that are not visible outwardly. Learning difficulties are experienced by some students in elementary schools, even experienced by students who study at the higher education level [10]. Operationally, learning difficulties can be seen from the reality in the field. Some students get scores below the minimum completeness criteria (KKM) in some of the subjects they follow. The student cannot complete the learning tasks given by the teacher within a certain period to achieve the student's competency goals.

Learning difficulties, also known as learning disorders, are disciplinary concepts used in education, psychology, and medical science. The first time suggested combining the names of disorders such as minimal brain dysfunction, neurological disorders, dyslexia, and developmental aphasia into one name, namely learning difficulties. According to the National Joint Committee for Learning Disabilities (NJCLD), the learning difficulties refer to a group of difficulties manifested in the form of difficulty in listening, conversing, reading, reasoning, or ability in the field of mathematics studies [2]. The disorder originates from within and is caused by central nervous dysfunction. However, these learning difficulties can occur simultaneously with other disturbing conditions, such as congenital disorders, social environment, and the influence of children's emotions. Environmental influences become one of the other disorder causes, such as cultural differences, inappropriate learning, and other psychogenetic factors. 
Students with learning difficulties are identified as having the following characteristics [10].

1. Based on IQ tests, have the normal level of intelligence (IQ) even above normal or slightly below normal. However, students with slightly below the average IQs have learning difficulties because they have difficulty taking IQ tests.

2. Have difficulty in some subjects, but shows good grades in other subjects.

3. Learning difficulties experienced by students with learning disabilities affect the learning success they achieve. These students can be categorized into lower achievers (students with learning outcomes that are below their potential).

Learning difficulties can be divided into three categories: difficulties in speech and language, difficulties in academic abilities, and other learning difficulties [2]. The classification is as follows.

1. Difficulty speech and language to be the earliest indication that can be detected. The most prominent feature is that a child will be slow in pronouncing language sounds, delays in conveying thoughts in the good and correct language, and delays in understanding language.

2. Difficulties in academic ability can be seen from reading delays (dyslexia), writing delays (dysgraphia), and difficulty in counting.

3. Another difficulty comes from external factors, namely the social environment and society.

\section{METHODS}

The method is the main way used to achieve the expected goals, while research is a space to get to the truth. This research is an attempt to collect data to be analyzed. The method that the researchers use is the experimental quantitative method. The quantitative approach views human behavior as predictable, objective, and measurable [25]. Therefore, the use of quantitative research with valid and reliable instruments and appropriate statistical analysis causes the research results to not deviate from the actual conditions.

The stages for analyzing the data are as follows. Data collection techniques in this study were taken through tests, interviews, and questionnaires. The steps that were carried out to analyze the data are as follows in Figure 1.

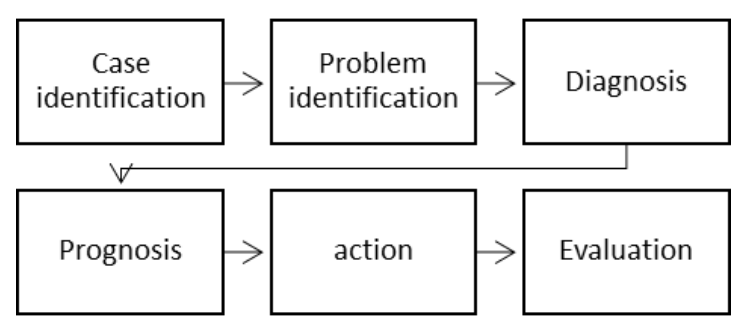

Figure 1 Flowchart of research procedure.s

In addition to using the experimental quantitative method to determine the improvement of students writing skills using the suggestopedia method, the researchers also use a case approach to determine the profile of students with writing difficulties, analyze and describe the factors that cause students to have difficulty learning to write. The steps based on the chart above are as follows [12].

1. Case identification, marking students suspected of having learning difficulties.

2. Problem identification, detecting problems experienced by students and the factors that cause learning difficulties.

3. Diagnosis, answering the difficulties experienced by students.

4. Prognosis, formulating the form of treatment.

5. Action, giving treatment for the writing ability of students with writing difficulties.

6. Evaluation, knowing how far the improvement of students' writing ability.

The experimental method is a research method that aims to explain the cause-and-effect relationship (causality) between one variable and another (variable $\mathrm{X}$ and variable $\mathrm{Y}$ ). To explain this causal relationship, researchers must carry out meticulous control and measurement of the research variables. The design used in this research is Pre-Experimental designs [20] due to the external variables that also influence the formation of dependent variables. This design helps obtain initial information on the questions in the research. The type of pre-experimental design used is One-Group Pretest-Posttest Design. In this design, 
there is a pretest before being given treatment. Thus, the results of the treatment can be known more accurately because they can be compared with the situation before being treated. This design can be described as follows.

$$
\mathrm{O}_{1} \times \mathrm{O}_{2}
$$

$\mathrm{O}_{1}=$ pretest value (before given treatment)

$\mathrm{O}_{2}=$ posttest value (after being given treatment)

$\mathrm{X}=$ treatment (use suggestopedia method)

The research was conducted at MTsN 11 Tasikmalaya, Tasikmalaya Regency, West Java. The population is one of the essential things and needs careful attention if researchers want to conclude a reliable and appropriate result for the area (area) or object of research [26]. The population of this study was all seventh-grade students, totaling seven classes with a total of 224 students. This study used quota sampling to determine the sample from the population with certain characteristics to the desired number. Of the 224 students, six students with writing difficulties were selected. The sample is part of the selected and represents the population [26].

\section{RESULTS AND DISCUSSION}

Several ways can be done in carrying out case activities, one of which is by looking at student achievements and teachers' diaries [13]. From the teacher's daily notes, it can be seen that the daily value development of children in terms of cognitive, affective, and psychomotor understanding. Here it can be seen that the six students have fewer daily grades when compared to the grades of their classmates. Indonesian language teachers stated that their average weakness was seen from their inability to master the quality of the text content (title, topic, and theme), the organization of the text content (sentence structure, coherence, and logic), and the choice and use of words. The difficulties they experience are because they tend to be passive and do not want to ask questions to the teacher or their classmates. Meanwhile, according to the homeroom teacher, the behavior of the six research subjects was different from other children, in which they tended to be quiet or even become a bully in class.

The next stage is problem identification. From this stage, it is known that the profiles of students with writing difficulties have the same pattern of study habits. From the results of interviews and tests conducted on research subjects, it was found that lack of motivation to learn and not being serious about participating in learning were factors that influenced students' difficulties in writing descriptive texts. In addition, another factor that influences the subject to have learning difficulties is family. Parents' indifference to children's learning difficulties and economic difficulties cause the subject to experience malnutrition. According to health experts, vitamin deficiency affects learning and behavioral disorders. Nutritionists recommend taking multivitamins C, B3, $\mathrm{B} 6, \mathrm{~B} 12$, and $\mathrm{E}$ because these vitamins are useful in tackling various disorders caused by malnutrition [10]. In addition, some children have to live far from their parents, and the subject's parents are divorced.

According to the diagnosis, difficulties experienced by students can be seen from the aspect of content quality, content organization, and low linguistic characteristics. Proper treatment is needed by giving treatment, namely the use of the suggestopedia method in writing learning activities to improve students' ability, especially in students with writing difficulties. After taking action on writing learning activities using the suggestopedia method, data processing is carried out to determine the effectiveness of the learning model.

Table 1. The Normality of the Pretest Data

\begin{tabular}{|c|c|c|c|c|c|c|}
\hline No & Subject & $\begin{array}{c}\text { Value } \\
(\mathrm{x})\end{array}$ & $\mathrm{z}$ & $\mathrm{f}(\mathrm{z})$ & $\mathrm{s}(\mathrm{z})$ & $\mathrm{S}(\mathrm{z})-\mathrm{f}(\mathrm{z})$ \\
\hline 1 & $\mathrm{EH}$ & 30.5 & -1.55 & 0.06 & 0.17 & 0.106 \\
\hline 2 & NM & 33.3 & -0.22 & 0.41 & 0.67 & 0.254 \\
\hline 3 & RBS & 33.3 & -0.22 & 0.41 & 0.67 & 0.254 \\
\hline 4 & VCR & 33.3 & -0.22 & 0.41 & 0.67 & 0.254 \\
\hline
\end{tabular}




\begin{tabular}{|c|c|c|c|c|c|c|}
\hline 5 & HWK & 36.1 & 1.11 & 0.87 & 1.00 & 0.134 \\
\hline 6 & MF & 36.1 & 1.11 & 0.87 & 1.00 & 0.134 \\
\hline Lots of data & 6 & & & \\
\hline average & 33.77 & &
\end{tabular}

Lo value $=\max (\mathrm{s}(\mathrm{z})-\mathrm{f}(\mathrm{z})=0.254$

The L value in the Lilifors table with a critical limit of $5 \%$ (value $=0.05)$ and $n=6$ is 0.361 .

Table 2. the Normality of the Post-Test Result Data
Lo $<\mathrm{L}$ is obtained in the Lilifors table, accepting Ho and rejecting $\mathrm{H} 1$.

Conclusion: The data from the pretest were normally distributed

\begin{tabular}{|c|c|c|c|c|c|c|}
\hline No & Subjek & Value $(x)$ & z & $f(z)$ & $s(z)$ & $S(z)-f(z)$ \\
\hline 1 & NM & 69.4 & -1.83 & 0.03 & 0.17 & 0.133 \\
\hline 2 & $\mathrm{EH}$ & 72.5 & -0.52 & 0.30 & 0.33 & 0.030 \\
\hline 3 & HWK & 75.0 & 0.54 & 0.71 & 0.67 & 0.040 \\
\hline 4 & RBS & 75.0 & 0.54 & 0.71 & 0.67 & 0.040 \\
\hline 5 & MF & 75.2 & 0.63 & 0.74 & 1.00 & 0.265 \\
\hline 6 & VCR & 75.2 & 0.63 & 0.74 & 1.00 & 0.265 \\
\hline \multicolumn{2}{|c|}{ Lots of data } & 6 & & & & \\
\hline \multicolumn{2}{|c|}{ average } & 73.72 & & & & \\
\hline \multicolumn{2}{|c|}{ Standard deviation } & 2.36 & & & & \\
\hline
\end{tabular}

Lo value $=\max (\mathrm{s}(\mathrm{z})-\mathrm{f}(\mathrm{z})=0.265$

The $\mathrm{L}$ value in the Lilifors table with a critical limit of $5 \%$ (value $=0.05$ ) and $n=6$ is 0.361 . obtained Lo $<\mathrm{L}$ in Lilifors table means accept Ho and reject $\mathrm{H} 1$.

1. Calculating the value of $t$. This test was conducted to determine the effectiveness of learning to write descriptive text using the suggestopedia method. The steps of the t-test carried out are as follows.
1) Hypothesis

$\mathrm{H}_{0}: \quad \bar{X}_{1}=$, The average pretest is the same as the average post-test

$\mathrm{H}_{1}: \quad \bar{X}_{1} \neq$, The average pretest is not the same as the average posttest

2) Data analysis of research results from the use of actions in learning to write descriptive text

Table 3. Data analysis of research results from the use of actions in learning to write descriptive text

\begin{tabular}{|c|c|c|c|c|c|}
\hline \multirow{2}{*}{ No } & Subjects & $\begin{array}{c}\text { Pre-test } \\
\text { Score } \\
\left(X_{1}\right)\end{array}$ & $\begin{array}{c}\text { Post-test } \\
\text { Score } \\
\left(X_{2}\right)\end{array}$ & $\begin{array}{c}\text { Difference } \\
(\mathrm{D})\end{array}$ \\
\hline 1 & EH & 30.5 & 72.5 & 42.0 & 1764.0 \\
\hline 2 & HWK & 36.1 & 75.0 & 38.9 & 1513.2 \\
\hline
\end{tabular}




\begin{tabular}{|c|c|c|c|c|c|}
\hline 3 & MF & 36.1 & 75.2 & 39.1 & 1528.8 \\
\hline 4 & NM & 33.3 & 69.4 & 36.1 & 1303.2 \\
\hline 5 & RBS & 33.3 & 75.0 & 41.7 & 1738.9 \\
\hline 6 & VCR & 33.3 & 75.2 & 41.9 & 1755.6 \\
\hline \multicolumn{2}{|c|}{ Total } & 202.6 & 442.3 & 239.7 & 9603.7 \\
\hline \multicolumn{2}{|c|}{ Average } & 33.8 & 73.7 & 40.0 & 1600.6 \\
\hline
\end{tabular}

1) Calculating the value

Obtained:

$$
\mathrm{t}_{\text {count }}=41.564
$$

2) View t table

For degrees of Freedom $(\mathrm{Dd})=\mathrm{N}-1=6-1=5$

Critical limit 5\% $(\alpha=0.05)$

$\mathrm{t}_{\text {table }}=\mathrm{t}_{(0.05 / 2)(\mathrm{Db})}=\mathrm{t}_{(0.025)(5)}=2.571$

3) Draw a Conclusion

It is found that $\mathrm{t}_{\text {count }}>\mathrm{t}_{\text {table, }}$, it means reject $\mathrm{H}_{0}$ and accept $\mathrm{H}_{1}$ y is $\quad \bar{X}_{1} \neq$. The pre-test score is not the same as the post-test score. Furthermore, we see that the average post-test score is higher than the pre-test score. To sum up, it can be concluded that the suggestopedia learning model can improve the ability to write descriptive texts for students with writing difficulties.

\section{CONCLUSION}

Based on the analysis and discussion that have been carried out, the use of the suggestopedia method is effective for students who have difficulty writing descriptive text. This can be seen from the increase in student scores after being given treatment using the suggestopedia method. Furthermore, it is expected that teachers can use this method to improve the difficulties students face related to learning difficulties. In addition, the suggestopedia method is expected to be an alternative in selecting learning methods in teaching and learning activities in the classroom.

\section{AUTHORS' CONTRIBUTIONS}

All authors conceived and designed this study. All authors contributed to the process of revising the manuscript, and in the end, all authors have approved the final version of this manuscript.

\section{REFERENCES}

[1] Anshor, et al, Pendidikan Bagi Anak Berkesulitan Belajar, Jakarta: Rineka Cipta, 2009.

[2] A. C. Alwasilah, Pokoknya studi kasus. Kiblat Buku Utama: Bandung. 2015.

[3] A. Suharsimi, Prosedur Penelitian Suatu Pendekatan Praktik, Penerbit: Rineka Cipta, Jakarta 2010.

[4] A. Parnawi, Psikologi belajar, Deepublish, 2019.

[5] H. Colliander, A. Fejes, The re-emergence of Suggestopedia: teaching a second language to adult migrants in Sweden, Language, Culture and Curriculum 34(1), 2021, pp. 51-64.

[6] L. Husna, An analysis of students' writing skill in descriptive text at grade X1 IPA 1 of MAN 2 Padang, Jurnal Ilmiah Pendidikan Scholastic 1(1), 2017, pp. 16-28.

[7] D. S. Iskandarwassid, Strategi pembelajaran bahasa, Bandung: PT. Remaja Rosdakarya, 2008.

[8] E. Istiyani, Improving Student Aptitude of Reading Narative Text Entiteled Cinderella by Using Modified Suggestopedia Method. [online]. Diakses dari https://www.academia.edu/3694819. 2021. 
[9] J. Martini, Kesulitan Belajar Perspektif, Asesmen, dan Penanggulangan nya, Bogor: Ghalia Indonesia, 2014.

[10] G. Keraf, Eksposisi dan deskripsi, Nusa Indah, 1981.

[11] K. Yin, Robert. Studi Kasus, Desain dan Metode. Depok: Raja Grafindo Persada. 2019.12

[12] A. S. Makmum, Psikologi Pendidikan. Bandung : Remaja Rosda Karya. 2007.

[13] B. Nurgiyantoro, Penilaian pembelajaran sastra berbasis kompetensi, Yogyakarta: BPFe, 2010.

[14] J. D. Parera, Menulis Tertib dan Sistematik. Bandung: Erlangga. 1987.

[15] D. Prasetya, K. Safitri, Metode Suggestopedia Sebagai Alternatif Dalam Meningkatkan Motivasi Belajar Siswa Sekolah Dasar, Trihayu: Jurnal Pendidikan Ke-SD-an 6.32020.

[16] D. Purworini, Model sugesti-imajinasi. [online]. Diakses dari http://berbahasabersastra.blogspot.com/2018/15/ sugestiimajinasi. 2011.

[17] B. Rahman, Sifat-sifat metode sugestopedia. [online]. Diakses dari http://bahasa-dan-sasttraindonesia83a.blogspot.com/2018/12/ metodesugestopedia-untuk-pembelajaran. 2011.
[18] J. C. Richards, T. S. Rodgers, Approaches and methods in language teaching. Cambridge university press, 2014.

[19] M. Siddik, Pengembangan Model Pembelajaran Menulis Deskripsi, Tunggal Mandiri Publishing, 2018.

[20] B. Prsetyo, L. M. Jannah. Metode penelitian kuantitatif. 2019.

[21] Tatang. Kemampuan Keterampilan Menulis Permulaan Huruf Arab Pada Siswa PAUD. [online]. https://www.docplayer.info.com. 2011

[22] T. H, Guntur, Menulis Sebagai Suatu Keterampilan Berbahasa, Edisi revisi. Angkasa: Bandung 2008.

[23] P. Trimantara, Metode sugesti-imajinasi dalam pembelajaran menulis dengan media lagu, Jurnal Pendidikan Penabur 5(4), 2005, pp. 1-15.

[24] D. Larsen-Freeman, Language teaching methods: Teacher's handbook for the video series, US Department of State, 1990.

[25] Y. W. Ariani, Using Suggestopedia Method to Develop the Students' Writing Skill, Universitas Ahmad Dahlan: Yogyakarta, 2014.

[26] A. M. Yusuf, Model Penelitian: Kuantitatif, Kualitatif, dan Peneletian Gabungan. Jakarta: PT Fajar Interpratama Mandiri. 2013. 